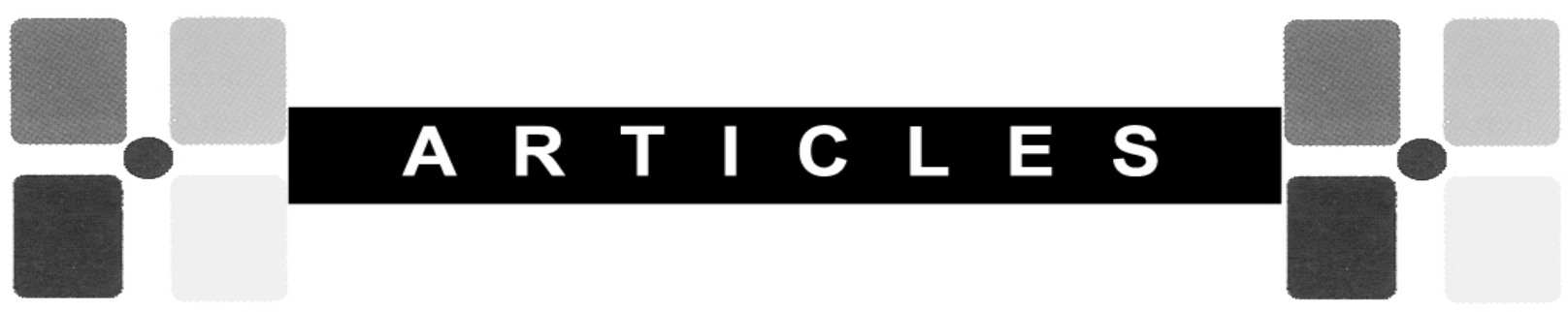

\title{
The Critical Success Factors for School and Community (J oint Use) Libraries in New Zealand
}

\author{
Vivienne Kaye D. Matthews \\ Akaroa Library, Christchurch City Libraries \\ and Philip J. Calvert \\ Victoria University of Wellington, New Zealand
}

\begin{abstract}
Joint use libraries in New Zealand are generally found in the form of School and Community Libraries, primarily in rural areas, but there is little information available about their effectiveness or success. Research was undertaken by surveying all identified joint use libraries in New Zealand and then following this with detailed Case Studies of three selected libraries. As these joint use libraries continue to be established in rural and urban areas of New Zealand, this research aimed to establish the Critical Success Factors for School and Community (Joint Use) Libraries in New Zealand. A comparison of these factors with those found in overseas literature on Joint Use Libraries has yielded guidelines to enable present and future manifestations of these libraries in New Zealand to be effective and successful.
\end{abstract}

A joint use library is one in which two or more separate library service providers cooperate to serve their user groups equitably in a shared facility. Joint use libraries (also known as dual use, combined use, school and community, school/public, university/public, or polytechnic/public libraries) have existed for nearly one hundred years. They have been established or are being considered in a number of countries including Australia, Canada, the United States of America, the United Kingdom and New Zealand. In the past they were often established to provide public library services in rural areas where a lack of funding made normal public library provision difficult, if not impossible, so sharing facilities with existing school libraries was a viable solution to the problem. In these cases they succeeded best when there were strong links between the school and the community.

In more recent times these library partnerships have continued to be developed for economic reasons. However, they are also developed to:

- encourage lifelong learning by allowing general public access to large university collections and professional reference staff;

- make larger public collections, superior information technology, and better staffing numbers available to school pupils.

Numerous failures of these partnerships have been documented and the chief reasons for negative results have been:

- a lack of perceived savings or economic advantage; 
- irreconcilable differences in philosophies between the partners;

- insufficient growth in funding for collections and information technology;

- low staffing levels;

- $\quad$ staff resistance to the concept;

- an inconvenient location and poor car parking facilities;

- poor marketing and insufficient signage;

- the reluctance of the public to use a library situated within a school.

Better outcomes for current and future joint-use libraries are entirely possible. Considerable research and study has been undertaken world-wide to identify the factors required to ensure the survival and success of these library partnerships. Extensive planning and consultation must occur before any implementation begins; there must be considerable effort made to secure commitment to the concept from all stakeholders; and a number of critical success factors must be accepted, understood and incorporated into their management.

There is very little information to be found about the success of this form of library service delivery in New Zealand. In the past these libraries seem to have been established to fill a library need in a fairly arbitrary fashion without much consideration being given to the ongoing support which would be required and the important factors necessary for their success. Joint-use school and community libraries are still being established in both rural and urban areas so an insight into the factors that make these libraries a success is increasingly important.

\section{Literature Review}

A review of the literature leads to the conclusion that joint-use libraries remain popular but can be controversial, and will probably always have degrees of success and failure which require careful planning to control.

Overseas events in the 1970s and 1980s largely shaped the joint-use libraries of today, and there is a considerable body of 'classic' literature covering these events in detailed case study form. Amey (1987, $p$. vii) includes a 514-item bibliography and makes the interesting point that while the literature was voluminous it mostly consisted of independent case studies from widely disparate communities and locations and with different forms of governance. Studies were conducted in Canada, United States, Australia and New Zealand (Haycock, 2006, 491) and the United Kingdom (McNicol, 2003b). The variation between the libraries made it hard to see patterns or themes in their success.

Most relevant to the New Zealand situation is the significant contribution that Bundy $(1994,1997, \& 1999)$ has made to the literature. He has undertaken extensive research projects especially in South Australia where joint use libraries are unique as they have a political mandate from the State government. His study tour of the forty-six South Australian rural joint use libraries in 1993 was then followed in 1997 by an extensive investigation of the history and management of these libraries which provided much detailed data in case study form. His follow up 1999 study consisted of visits to fifty-two joint use libraries throughout Australia and seven in the upper North Island of New Zealand.

His findings tend to highlight the problems that are inherent in applying the joint-use concept in practice because proper procedures, management structures and support systems are often left lacking. He concludes that it is essential to have current agreements between the main partners with all aspects of management and service provision covered, and also to have a stipulation for external review of the library service on a regular basis - probably every two years.

Bundy (2003) further elaborates on joint use libraries around the world and the factors affecting their successful implementation and management, as well as those that cause their failure. His assertion, however, that these libraries are generally very successful is at odds with the views expressed by six joint use library managers (Aird, Bergoc, Dunford, Hamblin, Perkins, \& Shepherd, 1998). They cite difficulties 
encountered because of funding reductions and vastly increased workloads, which have meant that successes are due more to the dedication and flexibility of staff rather than the joint use concept itself. While their objectivity may be called into question, Bundy's overview may also be glossing over serious problems in his enthusiasm to endorse the joint use concept.

In New Zealand joint use libraries followed the example of the then successful South Australia model when it became necessary to provide a different form of delivery for library services to rural areas. In the late 1930s the perceived disadvantage rural dwellers experienced in library services was being addressed by the Country Library Service, which provided book van services, small book depots in community facilities, and books by mail for very far-flung areas (Griffith, Harvey \& Maslen, 1997). However, in 1986 the National Library of New Zealand commissioned The Ministerial Review of the National Library's Services to Rural Areas, which was adopted in 1987 (Andrews \& Frater, 1987). This resulted in the demise of the Country Library Service and changes to library service delivery for rural areas in New Zealand. Andrews and Frater compiled a guide (1987) to provide procedures and criteria for these planned changes. The South Australian model of school/community libraries was deemed to be appropriate for New Zealand to adopt with the National Library providing various forms of assistance. Schools were believed to be the best base for developing rural library services, so twenty-three Area schools were initially selected to receive incentives in the form of book stock. The National Library book van service was replaced by loan collections to these libraries by 1990, and the existing School Library Service continued with the addition of microfiche readers and catalogues provided to the new joint use libraries.

However, in 1992, local government restructuring in New Zealand saw the end of much of the support given to school and community libraries by the National Library. Loan collections were discontinued because central government devolved the responsibility for library services to local authorities. Extra funding to compensate for this loss of support became a matter to be negotiated with each individual local authority.

The provision of library services to smaller rural communities has been, mostly, successfully achieved by the joint use concept, with benefits to the schools of a much larger book stock, better staffing levels and longer opening hours. These libraries provide a service where a separate public facility would not have been viable or economic, and give the added benefit of closer ties with the school community as well as the encouragement for continuing education.

In recent times there has been little written about the New Zealand joint use library experience. Bundy (2003) provides an overarching view of the experiences of joint use libraries around the world, describing both the larger number of school-community models and the smaller number of university-public ones. He asserts that one of the main advantages is the synergy of a joint use service - the whole is greater than the sum of the parts. He also states that ultimately it is the library staff who will make these partnerships succeed. He provides comprehensive checklists for planning proposed joint use libraries and describes the key factors that are vital for their success.

McNicol (2003a) undertook a survey of twenty-three dual use (joint use) libraries in the United Kingdom. She followed the survey with three case studies representative of the three types of locations where dual use libraries are commonly found in the United Kingdom, i.e., an isolated rural community, a less isolated village, and an urban community. Her study focused on the effects that these libraries have on the communities they serve, the factors affecting their success, their unique problems and unique benefits. She concluded that the number of joint use libraries is likely to increase as schools are encouraged to work more closely with local communities. This necessitates recommendations for best practices and guidelines for all aspects of managing these libraries, i.e., design, operation, service agreements, staffing, resource provision, and promotion. This recent research is of significant value and interest for the methodology used and the types of joint use libraries studied.

Haycock (2006), provides a very balanced overview of (what he calls) dual use libraries. He makes the humorous point that the term is dual, not duel, in reference to the many conflicts that can arise if planning and management are not done correctly. His ten criteria for success are very similar to those which 
consistently and continually appear in studies that investigate and assess the quality of services in joint use libraries.

Bundy and Amey (2006) describe the difficulties inherent in trying to evaluate joint use libraries because their uniqueness militates against benchmarking. This often means that problems go unrecognised until a crisis point is reached. They stress the importance of continuous self-evaluation and also external evaluation. A joint use library evaluation methodology is outlined using "Critical Success Factors." Goals are identified and the Critical Success Factors required to achieve these goals are outlined; this gives an effective mechanism for documenting progress and failures. "Experience suggests early investment in an ordered program of evaluation - together with the selection of the right staff - is the best guarantor of a durable joint use library, and one that is truly greater than the sum of its parts" (Bundy \& Amey, 2006).

\section{Objectives}

This research into joint use school and community libraries endeavoured to find which have been the most important factors for success in the New Zealand context.

A comprehensive list of factors considered necessary for success in overseas joint libraries has been gleaned from the available literature (e.g. Haycock, 2006; Bundy \& Amey, 2006; Bundy, 2003; McNicol, 2003b; Shier, 1999; Andrews \& Frater, 1987; Australian Library and Information Association, 2002).

Planning Factors:

- a driving force, initiator, specific reason or impetus;

- an independent feasibility study by a library consultant familiar with the joint use concept;

- professional advice during an extensive planning process;

- unequivocal commitment by all partners;

- promotion of the joint use concept to overcome negative preconceptions;

- determination of the population size and characteristics of the profile community to ensure that all needs are met;

- full and comprehensive communication and consultation with all parties affected, especially the community to be served;

- realistic attitude towards cost saving: savings expected by joining facilities are unlikely without compromising service levels;

- an undertaking that the level of service is at least equal or better than the two separate entities.

Location \& Physical Factors:

- if the site is located in school grounds there must also be reasonable proximity to other essential community facilities;

- $\quad$ site must be accessible, visible and have plenty of parking for all users;

- $\quad$ signage should be clear and unambiguous;

- $\quad$ building size must be adequate for both partners served;

- future proofing is ensured by the ability to increase size of facility;

- facilities, collection and services must be completely integrated, with no restriction of access to any resources;

- separate areas should be provided for group work, teaching and study;

- opening hours must reflect the needs of the users served.

Policy \& Management Factors:

- access to all users must be available during all operating hours - no groups excluded at any time;

- policies must be in place on all aspects of operation, e.g., censorship, Internet access, fines and charges;

- signed formal agreement between partners should cover all aspects of management including collection policies, funding, future development, staffing, maintenance and dissolution of the partnership; 
- management board representative of all parties and in advisory capacity to the library manager should develop policy, goals and budget priorities;

- excellent information technology provision and ongoing equipment and software support services must be provided;

- all parties commit realistic funding;

- collection development must be consistent with the needs of all users;

- goodwill, excellent communication, cooperation and tolerance of the differing philosophies of the partners should exist;

- if possible, the library should be part of a larger network;

- regular internal and external evaluation should be conducted.

Staffing Factors:

- integrated staffing structure with a single library manager who has regular communication with management board;

- adequate staffing levels with provision for professional development;

- ongoing commitment to the joint use concept by all staff;

- staff members who are flexible, open to different ideas, and trained to meet the needs of the different user groups.

In New Zealand there are about forty joint use libraries, and they generally occur as rural school-based public libraries in communities ranging in size from a few hundred to several thousand. There are exceptions, notably a new community and school library, opened in February 2006, which is located in the grounds of a High School and jointly serves its 1100 customers, plus a community of 30,000 residents in a suburban area of a large city.

The overseas studies give valuable information regarding the factors involved in the successful implementation and management of joint use libraries, but the lack of New Zealand research leaves a large gap in our knowledge of how these libraries are succeeding and whether they could be managed more successfully. New Zealand communities differ from those in Australia (Bundy, 1994, 1997,1999) and the United Kingdom (McNicol, 2003a) where the most recent studies have been done, and the level of support that joint use libraries receive in New Zealand could be vastly different as well as very variable depending on the negotiations and relationships with their partners.

The generally shared opinion of Bundy and McNicol that joint use libraries are beneficial to the communities they serve and should increase in number needs to be tested in the New Zealand situation to ensure that these are valid and objective premises and that there are not, in fact, significant systemic problems that need to be uncovered and resolved.

\section{Study Objectives}

This investigation had several objectives:

- to survey as many as possible of the existing school and community libraries in New Zealand as can be contacted and persuaded to participate;

- to select three examples of these joint use libraries and carry out a more detailed case study of each by observation and interviews with library staff;

- to ascertain by these research strategies which factors have been most critical to their survival and/or success, and which are only incidental;

- to formulate a list of critical success factors which have been most important in the survival of school and community library partnerships in New Zealand;

- to determine whether these success factors vary significantly from those identified by overseas studies;

- to gain an insight into how joint use libraries in New Zealand should be planned before implementation, and then managed, to give them the best chance of success. 


\section{Methodology}

The chosen method for this research was a mixed methods approach, which employs both quantitative and qualitative methods of data collection, i.e. numerical and text information, to provide a better understanding of the research problem, and captures the best of both approaches (Creswell, 2003). The integration of these methods provided diverse data to explain the divergent views found, and maximized the validation and enlightenment gained. The Sequential Explanatory Strategy was employed, whereby quantitative data was collected by means of a survey questionnaire addressed to librarians employed at the joint use libraries; the data received was then collated. Following this stage, three joint use libraries were selected as case studies for qualitative data gathering which, when analysed, gave a much richer, fuller picture than the survey data alone could give. The aim was to provide a clear understanding of the multiple factors contributing to positive or negative outcomes in joint use libraries in New Zealand and thereby identifying the factors critical for their success. Determining these factors will provide essential planning data for the future when proposed joint use facilities are being considered.

The entire population of New Zealand School and Community Libraries was surveyed. Thirty one libraries were identified, so sampling was unnecessary and undesirable. Once contact details had been obtained for all joint use libraries identified, a detailed questionnaire was sent with questions that covered physical location, proximity to community facilities, parking, signage, information technology facilities, collections, funding, staffing, support, management and perceived success. The results of the survey questions were collated in spreadsheet format. In this sequential model, some outlier or extreme cases were found, which diverged widely from the general results and these provided interesting data for consideration.

Three joint use libraries were selected for further in-depth case study research. One outlier view and two representative views were studied.

- Interviews. Time and feasibility constraints meant that only the librarians were able to be interviewed instead of the wide range of stakeholders which would have been desirable. Questions were asked and opinions sought to build up a broad and detailed picture of the successes, failures, problems and benefits perceived in each library situation.

- Observation. The facilities, collections and equipment, plus the general atmosphere, workability, staff and user relations, were all observed to gain an insight into the validity of the interview results.

- Analysis. The data obtained was organized and transcribed so that results could be interpreted and compared. The qualitative data provided more specific and explanatory findings as well as uncovering more details on divergent and common themes and issues.

\section{Data Analysis}

Thirty-four surveys were sent out because in three cases initial feedback was received which indicated that completely different opinions could be expected from the school versus community librarians at those libraries. Effectively, there were replies from nineteen library respondents: a 56\% response rate.

Comparisons of the numerical variables such as population size, circulation figures, total collection size and staffing have been attempted but only give a small part of the overall results picture. However, the table does indicate the widely disparate results when circulation is compared to population, and when circulation is compared to population, and when staffing levels are compared to circulation.

Figure 1: A comparison of the joint use libraries

\begin{tabular}{|l|l|l|l|l|l|}
\hline $\begin{array}{l}\text { COMMUNITY } \\
\text { POPULATION }\end{array}$ & $\begin{array}{l}\text { SCHOOL } \\
\text { POPULATION }\end{array}$ & $\begin{array}{l}\text { COLLECTION } \\
\text { SIZE }\end{array}$ & $\begin{array}{l}\text { CIRCULATIONI } \\
\text { ANNUM }\end{array}$ & $\begin{array}{l}\text { STAFF HRS. } \\
\text { IWEEK }\end{array}$ & $\begin{array}{l}\text { VOLUNTARY } \\
\text { HRS.IWEEK }\end{array}$ \\
\hline 3,000 & 162 & 20,643 & 20,000 & 42 & 0 \\
\hline 1,500 & 250 & 16,835 & 24,505 & 56 & 12 \\
\hline 2,000 & 200 & & 40,000 & 27.5 & 3 \\
\hline
\end{tabular}




\begin{tabular}{|l|l|l|l|l|l|}
\hline & 400 & 12,988 & 16,301 & 37.5 & 7 \\
\hline 500 & 147 & 6,330 & 2,648 & 11 & 0 \\
\hline & 320 & 11,500 & 20,500 & 40 & 22 \\
\hline 300 & 75 & & & 1 & 7 \\
\hline 1,800 & 1,100 & 65,000 & 579,000 & 570.5 & 0 \\
\hline & 320 & 10,000 & 19,000 & 42 & 10 \\
\hline 900 & 290 & \multicolumn{1}{|l|}{$\begin{array}{l}\text { 8118+ loan } \\
\text { collections }\end{array}$} & 12,950 & 8 & 20 \\
\hline 600 & 120 & $\begin{array}{l}800 \text { PA loan } \\
\text { collection }\end{array}$ & 150 & 20 & 40 \\
\hline 456 & 180 & 5,000 & 4,464 & 32.5 & 0 \\
\hline 2,000 & 180 & 15,000 & 38,000 & 50 & 0 \\
\hline
\end{tabular}

A general summary of results and comments is provided here.

Figure 2: Summary of the survey results

\begin{tabular}{|c|c|}
\hline BACKGROUND: & SUMMARY \\
\hline Year opened & $1981-2006$ \\
\hline Reasons for formation & $\begin{array}{l}\text { Resource sharing in small areas. National Library } \\
\text { encouragement because of the demise of Country Library } \\
\text { Service and devolution of rural library service provision } \\
\text { from Central to Local Government. }\end{array}$ \\
\hline Management Committee & $Y=16, N=3$ \\
\hline Importance of Management Committee & Very $=2$, Important $=11$, Not $=2$, Don't Know $=4$ \\
\hline Formal Management Agreement & $Y=18, N=1$ \\
\hline Communication between partners & Very $=7$, Average $=11$, Poor $=1$ \\
\hline Library Manager & $Y=16, N=3$ \\
\hline Service or resource restrictions & $Y=5, N=14$ \\
\hline Availability all users during opening hours & $Y=15, N=4$ \\
\hline Meeting School needs & Very $=16$, Average $=2$, Poor $=1$ \\
\hline Meeting Community needs & Very $=15$, Average $=4$ \\
\hline \multicolumn{2}{|l|}{ COMMUNITY: } \\
\hline$\overline{\text { Community type }}$ & Urban $=2$, Rural $=17$ \\
\hline School type & Primary $=2$, Secondary $=5$, Area $=12$ \\
\hline Community population & $300-30,000$ \\
\hline School population - pupils/staff & $75-1,100$ \\
\hline Strong links between School \& Community & $\mathrm{Y}=19$ \\
\hline Importance of Community support & Very $=11$, Important $=8$ \\
\hline Community Education Programmes & $Y=9, N=10$ \\
\hline Importance of Library in Lifelong Learning & Very $=5$, Important $=9$, Not $=4$, Don't Know $=1$ \\
\hline \multicolumn{2}{|l|}{ BUILDING \& LOCATION: } \\
\hline Purpose built/School Library adapted & Adapted in some way $=10$, Purpose Built $=9$ \\
\hline Size adequate & $Y=17, N=2$ \\
\hline Room for expansion & $Y=15, N=4$ \\
\hline Importance of ability to expand & Very $=9$, Important $=5$, Not $=3$, Don't Know $=2$ \\
\hline Suitability of location & $Y=16, N=3$ \\
\hline Importance of location to School & Very $=17$, Important $=1$, Not $=1$ \\
\hline Importance of location to Community & Very $=10, \operatorname{Important}=4$, Not $=5$ \\
\hline
\end{tabular}




\begin{tabular}{|c|c|}
\hline ACCESS \& SIGNAGE: & \\
\hline Parking adequate \& convenient & $Y=18, N=1$ \\
\hline Disabled access & $Y=16, N=3$ \\
\hline Signage boldness & $Y=12, N=7$ \\
\hline Signage clarity about joint use & $Y=11, N=8$ \\
\hline Importance access \& signage to usage & Very $=11$, Important $=2$, Not $=4$, Don't Know $=2$ \\
\hline Adequacy opening hours & $\mathrm{Y}=16, \mathrm{~N}=2$, Don't Know $=1$ \\
\hline Importance of different opening hours & Very $=1$, Important $=8$, Not $=9$, Don't Know $=1$ \\
\hline STAFFING: & \\
\hline Paid staffing hours per week: & \\
\hline Teacher Librarian & Rare: 1 - 2 hours per week max. \\
\hline Librarian/Library Manager & 8 - 570.5 hours per week \\
\hline Library Assistant & 10 - 42 hours per week \\
\hline Staffing levels adequate & $Y=15, N=4$ \\
\hline Staff committed to joint use concept & $Y=18, N=1$ \\
\hline Importance staff attitudes to success & Very $=15$, Important $=3$, Don't Know $=1$ \\
\hline Volunteers & $Y=13, N=6$ \\
\hline Voluntary hours per week & 3 - 40 hours per week \\
\hline Importance of volunteers & Very $=13$, Important $=1$ Not Applicable $=5$ \\
\hline INFORMATION TECHNOLOGY: & \\
\hline IT funding & School $=8$, Council $=11$ \\
\hline Availability of good IT support & $Y=16, N=3$ \\
\hline Internet/Email School & $Y=15, N=4$ \\
\hline Internet/Email Community & $Y=12, N=7$ \\
\hline Catalogue Online to classrooms & $Y=13, N=6$ \\
\hline WebOPAC for Community & $Y=4, N=13$, Soon $=2$ \\
\hline Importance of good IT for success & Very $=16$, Important $=3$ \\
\hline FUNDING \& COLLECTION: & \\
\hline Employment of staff: & \\
\hline School BOT hours per week & $1-65$ hours per week \\
\hline Council hours per week & 0 - 505.5 hours per week \\
\hline Collection funding: & \\
\hline School BOT \% & $10 \%-100 \%$ \\
\hline Council \% & $0 \%-90 \%$ \\
\hline Collection development responsibility & Librarian $=5$, School $=1$, Council with School $=3$, Both $=6$ \\
\hline Collection integrated & $\mathrm{Y}=18$ (2 with separate ownership), $\mathrm{N}=1$ \\
\hline Collection size & $5,000-65,000$ \\
\hline Issues per annum & $2,820-579,000$ \\
\hline Adequacy collection - School & Very $=8$, Average $=10$, Don't Know $=1$ \\
\hline Adequacy collection - Community & Very $=9$, Average $=9$, Don't Know $=1$ \\
\hline Day to day running costs & School $=14$, Council $=1$, Both $=4$ \\
\hline Funding percentage equitable & $\mathrm{Y}=11, \mathrm{~N}=8$ \\
\hline Importance of Principal \& BOT & Very $=15$, Important $=4$ \\
\hline Importance of Council & Very $=14$, Important $=2$, Not $=3$ \\
\hline Part of Larger Library Network & $Y=17, N=2$ \\
\hline Importance of Network & Very $=13$, Important $=3$, Not $=1$, Not Applicable $=2$ \\
\hline Evaluation & $Y=13, N=4, Y($ School $) \& N($ Cty $)=2$ \\
\hline Importance of Evaluation & $\begin{array}{l}\text { Very }=11, \text { Important }=4, \text { Not Applicable }=3, \text { Don't Know }= \\
1\end{array}$ \\
\hline Success of Partnership & Very $=15$, Average $=3$, Poor $=1$ \\
\hline
\end{tabular}




\begin{tabular}{|l|l|}
\hline COMMENTS: & Council have contracted library services to school \\
\hline & $\begin{array}{l}\text { Detailed agreement from beginning would have prevented } \\
\text { difficulties and meant fairer sharing of expenses }\end{array}$ \\
\hline & $\begin{array}{l}\text { School pay majority of costs; better agreement would have } \\
\text { helped }\end{array}$ \\
\hline & $\begin{array}{l}\text { Mutual respect and being open to experimentation are } \\
\text { important }\end{array}$ \\
\hline & $\begin{array}{l}\text { Staff attitudes vital: bad in past, good now, so much more } \\
\text { successful }\end{array}$ \\
\hline & $\begin{array}{l}\text { Very successful mostly due to excellence of staff team } \\
\text { Council on better signage, and funding for a late night from }\end{array}$ \\
\hline & $\begin{array}{l}\text { Future doubtful because of changing community } \\
\text { circumstances }\end{array}$ \\
\hline & $\begin{array}{l}\text { Support from all has given community a library to be proud } \\
\text { of }\end{array}$ \\
\hline & $\begin{array}{l}\text { Council doesn't fund; community fundraises for IT and } \\
\text { books }\end{array}$ \\
\hline Better disabled parking needed - is in planning stage \\
\hline & $\begin{array}{l}\text { School supervision of students during lunch breaks } \\
\text { important }\end{array}$ \\
\hline $\begin{array}{l}\text { Book collections from district's main library supplement } \\
\text { stock }\end{array}$ \\
\hline
\end{tabular}

Analysis of the Survey Results Summary (Figure 2) indicates interestingly positive responses from the majority of the school and community libraries:

Background:

- $84 \%$

- $95 \%$

- $37 \%$

- $84 \%$

- $74 \%$

- $79 \%$

- $84 \%$

- $79 \%$

management committee, which $68.5 \%$ consider to be very important, or important

formal management agreement

very good communication between partners, $58 \%$ average, $5 \%$ poor

library manager with overall responsibility

no service or access restrictions for users

available to all user groups during opening hours

meet school needs very well, $11 \%$ average, $5 \%$ poor

meet community needs very well, $21 \%$ average

Community:

- $90 \%$

- $64 \%$

rural populations

based in area schools: $26 \%$ secondary, $10 \%$ primary

- $100 \%$

- $100 \%$

- $47 \%$

strong links between school and community

community support very important or important

community education programmes provided

- $73 \%$

library very important or important for lifelong learning

Building \& Location:

- $53 \%$ school buildings adapted, $47 \%$ purpose built

- $89.5 \%$ library size was adequate

- $79 \%$ room for expansion if required

- $73 \%$ ability to expand very important or important

- $84 \%$ situated in convenient locations for all users

- $95 \%$ location was very important or important, for school

- $74 \%$ location very important or important for community 


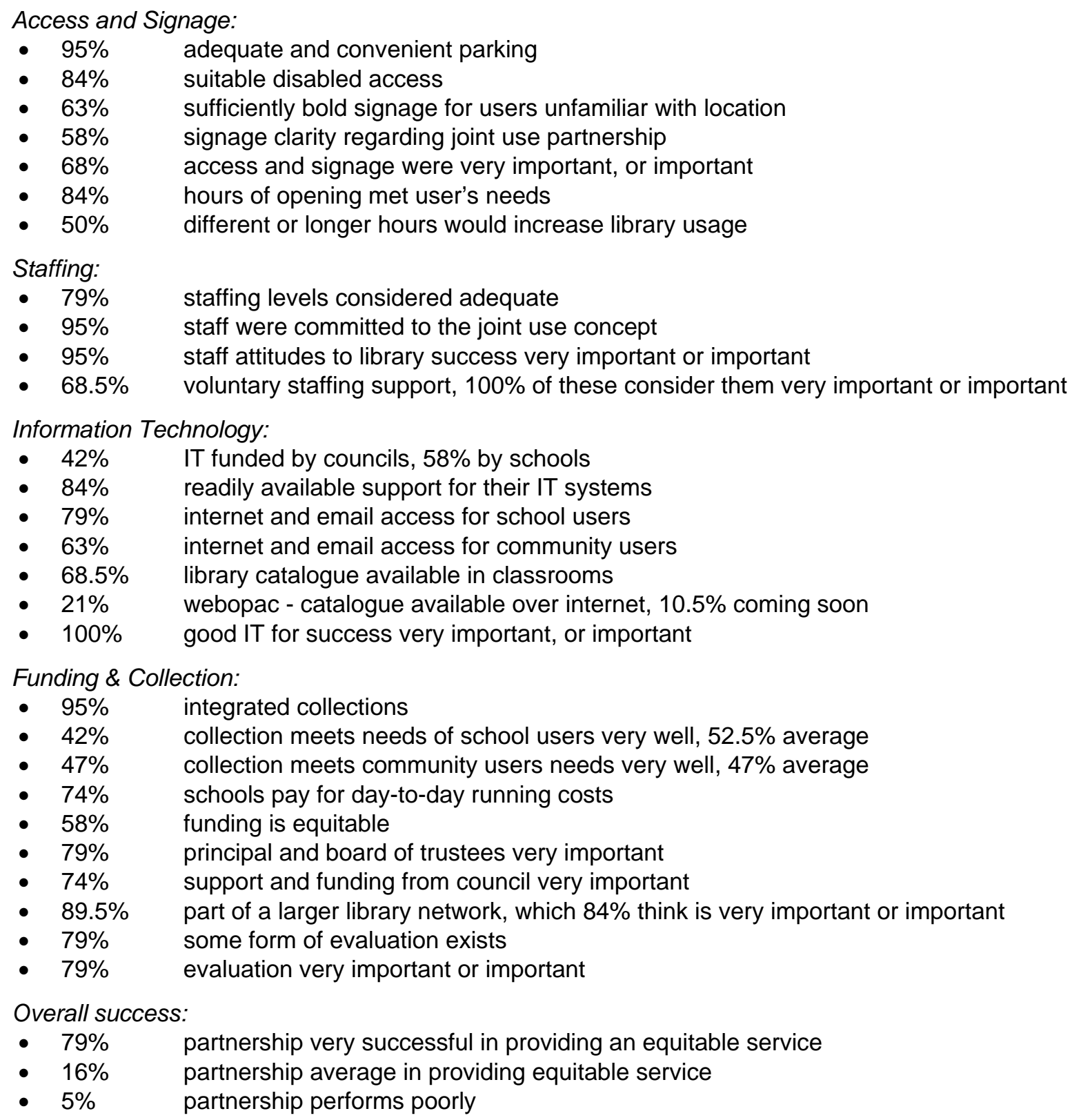

The questionnaire endeavored to survey the majority of factors deemed to be important for the success of joint use libraries. The response rate was not as high as desired, at $56 \%$, and it could be surmised that important results may be missing, most significantly from those partnerships that are failing. However, the majority who did respond painted an optimistic picture of the successes of joint use libraries in New Zealand.

- Very good results were demonstrated for the following factors: management, physical locations, size, ability to expand, access, community support, staff attitudes, part of larger network, and success of partnership in providing an equitable library service.

- Good results were demonstrated for the following factors: availability to all users during opening hours, no service or resource restrictions, communication between partners, meeting school needs, meeting community needs, staffing levels, information technology, and evaluation.

- Average results were demonstrated for the following factors: community education programmes, importance of library for lifelong learning, signage boldness and clarity, different opening hours, 
availability of Internet and email, adequacy of the collection for school users, adequacy of collection for community users, and equity of funding.

\section{Case Study Analysis}

The three case studies elaborated on the inevitably limited data obtained from the surveys. It is interesting that in the case of the two older rural libraries, staff and management have been able to keep up with technological changes and make necessary changes in attitudes and philosophy to accommodate their changing circumstances. Funding has been found for computerizing library systems and updating these when necessary. Generally, the collections have been managed well, and provide good resources for both sets of users. With the network changes that have also occurred in both libraries, borrowers can now access a wider range of materials. Internet capabilities have also allowed access to online resources. Voluntary help, which was vital in the early days of both these libraries, has diminished in importance and availability, but staff are coping with this change and managing to provide improved service levels. Staff flexibility, goodwill, communication and willingness to embrace change, as well as seek it out, is impressive and has played a large part in the success of these two libraries.

The third case study of a recently opened urban school and community library is very interesting because all nine planning factors identified in the objectives section were faithfully adhered to. The eight location \& physical factors have been met. The ten policy and management factors have been met with the possible exception of the philosophies of the partners; the council does appear to dominate in this area. The four staffing factors have been considered and are being adhered to except for the integrated staffing structure.

These combined results provide excellent data for the formulation of the critical success factors.

- a formal management agreement

- library manager with overall responsibility

- community support

- adequate size with room for expansion

- convenient location for all users

- good parking and access

- convenient opening hours for all users

- adequate staffing levels

- staff committed to the joint use concept

- volunteer staffing

- up-to-date information technology and technical support

- integrated collection

- no restriction on services, resources or access for user groups

- belonging to a larger network

- $\quad$ support and funding from school

- $\quad$ support and funding from council

- external and internal evaluation

- good will, flexibility, tolerance and communication.

\section{Summary}

The three primary objectives of this research were:

- to formulate a list of critical success factors important for the survival of school and community libraries in New Zealand, which was done using the data collected quantitatively and qualitatively

- to determine whether these factors varied significantly from those identified by overseas studies and literature

- to gain an insight into how future joint use libraries in New Zealand should be planned and managed to maximize their chances of success. 
The list of critical success factors provides an interesting platform to compare with the comprehensive list of factors which have been gleaned from the available literature.

- Location and Physical Factors: Most of these factors can be found in the Critical Success Factor list, the exceptions being signage, and separate areas for group work, teaching and study. Signage is poor for some libraries but because of their location in small communities it is not considered important.

- Policy \& Management Factors: Again most of these factors can be found in the Critical Success Factor list, one exception being Management Boards which were discovered to be serving little purpose and seem to be in existence in case of emergencies or as fund-raising bodies. Goodwill, communication, flexibility and tolerance seem to exist as a part of the basic synergy of the successful partnerships but should not be taken for granted.

- Staffing Factors: Integrated staffing often does not occur, but indications are that it is preferable and is something that will be worked towards in the future in most cases. Adequate staffing levels are open to interpretation - the opinions will vary between staff and management.

- Planning Factors: These factors have all been adhered to in the planning that was undertaken for the development of the one joint use library studied closely.

It seems clear that any future development of joint use libraries in New Zealand should, at the very least, ensure that they follow the list of critical success factors. However, they will be more assured of success if they follow the comprehensive lists of planning and management factors as described above, which incorporate even more detailed guidelines, and have proved to be just as relevant to the New Zealand circumstances as they are to overseas.

\section{Conclusion}

It is interesting to note that there are no significant variations between the list of critical success factors identified in this research and the list of factors found in the overseas literature. The only variation of note could be the fairly strong reliance on volunteers that is still to be found in some of the joint use libraries in New Zealand, and this will be because funding has been scarce and those communities are still willing and able to provide voluntary support.

While it could be argued that the survey results are not conclusive as any failing or unsuccessful libraries may not have responded, it is in the nature of research that one can only work with the results received. The other negative of the survey was the lack of explanatory detail which could be achieved by such a process. The only way to get the fully detailed picture that the researcher desired would be to undertake case studies of each library.

It would seem that many of the joint use libraries have survived and succeeded because of a strong determination on the part of their communities and the library staff to overcome obstacles such as funding shortages and philosophical differences between the partners. Management structures, procedures and support systems have been improved and funding increases have been negotiated when necessary. Librarian workloads have changed and increased but do not seem to be considered an insurmountable problem. Serendipitous findings came in the form of the generally very positive library staff attitudes encountered, the generous amount of time and help received, plus the very encouraging overall results of the research.

The overseas literature tends to paint a picture of failure and disharmony in many joint use libraries but this research did not find evidence to support that view, except in one instance. The future of joint use libraries in New Zealand looks very positive if past results are to be relied on. Provided that all the planning and management factors, as described, are carefully observed, future manifestation of these libraries stand a very good chance of success and should be able to provide excellent library services to their schools and communities. 


\section{References}

Aird, G., Bergoc, A., Dunford, H., Hamblin, D., Perkins, P., \& Shepherd, C. (1998). Joint use libraries in Australia: practitioner perspectives. Australasian Public Libraries and Information Services, 11, 174190.

Amey, L. J. (1987). Introduction. In L.J. Amey (ed.) Combining libraries: the Canadian and Australian experience (p.vii). Metuchen, NJ: Scarecrow Press.

Andrews, G., \& Frater J. (1987). School/community libraries in New Zealand. Wellington, NZ: National Library of New Zealand, and Department of Education.

Australian Library and Information Association. (2002). amended 1996, 2002. Statement on joint-use libraries. Retrieved from August 20, 2006, from http://www.alia.org.au/policies/joint-use.html

Bundy, A. (2003). Joint-use libraries: the ultimate form of cooperation. In G. McCabe \& J. Kennedy (Eds.) Planning the Modern Public Library Building (pp. 129-148). Westport, CT: Libraries Unlimited.

Bundy, A. (1999). For the public good: joint use libraries in Australia and New Zealand. Professional Experience Program Leave Report 1 July - 1 December 1999. Retrieved April 28, 2007, from the University of South Australia Web site: http://www.library.unisa.edu.au/about/papers/public.pdf

Bundy, A. (1997). Widened horizons: the rural school-community libraries of South Australia. Adelaide, S.A.: Auslib Press.

Bundy, A. (1994). At the crossroads: rural school community libraries in South Australia in 1993. Adelaide, S.A.: University of South Australia.

Bundy, A., \& Amey, L. (2006). Libraries like no others: evaluating the performance and progress of joint use libraries. Library Trends, 54, 501-518.

Bundy, A., \& Amey, L. (2003). Best investment: an assessment of the potential of a joint use high school and public library at Upper Riccarton, Christchurch. Report commissioned by Christchurch City Council and Riccarton High School.

Christchurch City Libraries. (2004). Upper Riccarton Library. Retrieved August 8, 2005, from http://www.library.christchurch.org.nz/UpperRiccarton

Creswell, J. W. 2003. Research design: qualitative, quantitative, and mixed methods approaches (2nd ed.). Thousand Oaks, CA: Sage.

Curral, S. C., \& Towler, A. J. (2003). Research methods in management and organisational research: towards integration of qualitative and quantitative techniques. In A. Tashakkori \& C. Teddlie (Eds.) A. Handbook of Mixed Methods in Social \& Behavioural Research (pp. 513-526). Thousand Oaks, CA.: Sage.

Griffith, P., Harvey, R., \& Maslen, K. editors. (1997). Book \& print in New Zealand: a guide to print culture in Aotearoa. (pp. 173-194). Wellington, NZ: Victoria University Press.

Haycock, K. (2006). Dual use libraries: guidelines for success. Library Trends, 54, 488-500.

McNicol, S. (2003a). Dual use public and school libraries in the U.K. Birmingham: University of Central England.

McNicol, S. (2003b). Joint use libraries in the U.K. Australasian Public Libraries and Information Services, 16, 81-90.

Shier, C. (1999). Resource sharing: case study of a new joint use library in South Australia. Australasian Public Libraries and Information Services, 12, 123-126.

Teddlie, C., \& Tashakkori, A. (2003). Major issues and controversies in the use of mixed methods. In A. Tashakkori \& C. Teddlie (Eds.) A. Handbook of Mixed Methods in Social \& Behavioural Research (pp. 3-50). Thousand Oaks, CA: Sage.

Vivienne Kaye D. Matthews is Associate Community Librarian at Akaroa School \& Community Library. Email: kaye.matthews@ccc.govt.nz

Philip J. Calvert is Senior Lecturer, School of Information Management at Victoria University of Wellington, New Zealand Email: philip.calvert@vuw.ac.nz 